\title{
Assessment on Impact of Live Animal Export on Meat Export Performance in Ethiopia; Policy Implications
}

\author{
Gezahagn Dugassa Mamo \\ Correspondence: Ethiopian Meat and Dairy Industry Development Institute (EMDIDI), Market Research Directorate
}

Received: July 21, 2019

Accepted: August 20, 2019

Online Published: August 21, 2019

doi:10.11114/bms.v5i3.4467

URL: https://doi.org/10.11114/bms.v5i3.4467

\begin{abstract}
Ethiopia has one of the largest livestock populations in Africa. Due to lack of livestock market structure, performances, prices are poor and inadequate for designing policies and marketing system, the sector has remained stagnant. Despite fluctuation over years, the exports of meat (16,877 tonnes) and live animals (472,041 head) have significantly increased in 2010 -2012 Ethiopian Fiscal Year (EFY), recording $69 \%$ increment from the previous years (kefyalew,2011). In 2018/19 EFY live animal contributes 33\% of the earning, while $67 \%$ was obtained from meat export (ERCA, 201819). However, lack of export routes and ports, illegal live animal trade, shortage of live animal and lack of appropriate breeding programs are some of the main challenges faced to the sector (kefaylew,2011). The presence of large livestock population with diverse and adaptable genotypes, and diverse agro-ecologies for production of different types of livestock; expansion of agro-industries and the increase of by product feedstuffs allowing for enhanced productivity; proximity of the middle east countries, high demand for meat and live animals including the domestic market are some of the opportunities that the sectors have. Therefore, the country would have been benefited more from the sector if the aforementioned challenges have been overcome. (Ameha,2011)
\end{abstract}

Keywords: live animal, meat, export, challenges, Ethiopia

\section{Introduction}

Ethiopia has one of the largest livestock populations in Africa. Livestock in Ethiopia provides draught power, income for farming communities, means of savings and investment and is an important source of foreign exchange earnings to the nation (Arend, 2006). The sub sector contributes 12 and 33\% to the total Gross Domestic Product (GDP) and agricultural Gross Domestic Product (GDP), respectively, and provides livelihood for $65 \%$ of the population (LMA, 2001).

Agriculture accounts for 46.3 percent of the nation's Gross domestic Product (GDP), 83.9 percent of exports, and 80\% of the labor force. Ethiopia's livestock population is believed to be the largest in Africa, and livestock accounted for $10.6 \%$ of Ethiopia's export income, with leather and leather products making up 7.5\% and live animals 3.1\% (CSA, 2006/7).

There are 13 export abattoirs and 1 slaughter byproduct processing company in Ethiopia. They have 200,300 ton sheep and Goats meat, and 130,411 ton beef meat production capacity per a year. This shows that, they need $(10,739,125$ head) live animals $(9,435,015$ head sheep and Goats, and 1,304,110 head beef) to use as an input per a year. However the country cannot used the opportunities and the average production of an abattoir per year is not more than $40 \%$. There are different problems that hinder the export performance of Ethiopian meat, from those shortage of live animal have the Lion share. All export abattoirs have almost common requirements of live animal purchase depending on their customer interest. Their demand of live animals area based arid and semi-arid (kola) areas of the country, weight, sex (Male), health etc. These criteria results shortage of live animal for export abattoirs, but the other hidden cause is live animal export.

However, current knowledge on livestock market structure, performance and prices are poor and inadequate for designing policies and institutions to overcome perceived problems in the marketing system. Knowledge on how marketing routes and systems could contribute to the spread of diseases and the implications of these for national and international trade in livestock is also highly inadequate to design any policy or institutional innovation to improve marketing for the benefit of the poor. 
Formal live animal exports are predominantly cattle (70\%). Meat exports are almost entirely from sheep and goats, and hides and skins are primarily from cattle. Trends over the last 10 years show meat becoming increasingly important to exports relative to live animals (Sintayehu et al., 2010). In 2009/10 budget year, 36\% and 28\% increment of meat export in volume and value terms, respectively, when compared with the previous year (2008/09). Compared with 2008/09, the number and value of live animals exported in 2009/10 was decreased by 55\% and 15\%, respectively (Trade bulletin, 2010).

\subsection{Objectives of the Study}

The overall objective of this review study is to assess the impact of live animal export on meat export performance in Ethiopia, for the purpose of policy change.

In addition to the above general objective, the research have the following specific objectives.

- To assess the trends of meat and live animal export in Ethiopia.

- To evaluate the impacts of live animal export on meat export performance.

- To recommend the best policy direction for the government.

\subsection{Statement of the Problem}

Lack of live animal supply and illegal trade are the most common problems for both live animal and meat exporters in Ethiopia. Ethiopian live animal export performance was decreasing because of different reasons, but meat export was increasing from year to year. One of the most challenge for meat export is lack of slaughter animal supply. It is encountered because of different reasons, but live animal export have the great share.

\subsection{Significance of the Study}

The main importance of this review was to address the impact of live animal export on Ethiopian meat export performance. Although few studies have provided some evidence on Ethiopian meat and live animal export challenges and opportunities still remained unexplored. The paper tries to fill this lack of evidence by extending the issue to the specific context, and direct the government to change policy towards meat and live animal export.

\section{Methodology}

The review was designed to answer the research question posed and attain the general and specific objective of the research. Analytical study uses information already available and analyzes these to make critical evaluation of information. Accordingly, the review addressed major live animals and all export abattoirs found in Ethiopia.

Both primary and secondary sources of data were used for this review. Primarily, data were obtained through questionnaire, observation, unstructured interview for respected bodies like meat exporters, live animal exporters, and government organizations. Aannual report of EMDIDI, export data of Customs, Journals and articles were used as a source of secondary data. Data were analysed by using quantitative descriptive data analysis and presentation methods; table, graph, percentage and average, mean, median.

\section{Review of the Literature}

Formally, Ethiopia exports approximately 200,000 livestock annually (Yacob and Catley 2010). This is significantly higher than the annual official exports of cattle (12,934 head), sheep (13,554 head) and goats (1,247 head) between 1998 and 2003 (Asefaw and Mohammad, 2007). This shows the growth of the formal channel since 2004 as a result of increased government oversight of the sector. Of the 200,000 livestock exported formally, approximately 40,000 cattle are exported from Amharic to Sudan, while smaller volumes of livestock are exported formally to Somalia and Kenya. The majority, however, is exported to Djibouti.

Black Head Somali and Afar sheep, as well as, the Somali and Afar goat breeds are the most preferred Ethiopian sheep and goat breeds exported, especially to the Middle East market (Ameha, 2011). Live animal export is the full many challenges; illegal trade, liability/credit payment, middlemen interference, lack of adequate quarantine and transport services, complex banking services etc (Kefyalew, 2011)

Ethiopia has some of the important opportunities influencing the meat and live animals industry, particularly the export sector (Ameha, 2011). The country has large livestock population with diverse and adaptable genotypes; diverse agro-ecologies for production of different types of livestock; government interest and support to the livestock industry; increasing number of export abattoirs like (Frigorico Boran Foods PLC/ Allana) which have the capacity of slaughtering 6,000 head of Sheep and goat, and 3,000 heads cattle per a day. Live animal exporters; the expansion of agro-industries and the increment of by-product feedstuffs allowing for enhanced productivity; proximity to Middle Eastern countries and adaptation of importing countries to the taste of Ethiopian animals; and high demand for meat and live animals 
including the domestic market. There is a large potential to expand Ethiopian meat exports to the Middle East if the value chain actors in Ethiopia meet export market standards (Ameha, 2011).

\section{Results and Discussions}

Ethiopian Meat and Live Animal Export Trends

The history of live animal export in Ethiopia is about two decades back. The export performance was increasing until 2011/12 EFY and became decline after. The most exportable animal in live was sheep (4.5 million $\mathrm{Kg}$ ) per year. It was decreasing by $24.5 \%$ or $8,000 \mathrm{Kg}$ per year, indicates that there are some challenges to be solved to sustain the currency earnings from the sector. (ERCA, annual report)

Table 1. Live animal export performance trends

\begin{tabular}{|c|c|c|c|c|c|c|c|c|c|c|c|c|c|c|}
\hline $\begin{array}{l}\mathrm{S} \\
\mathrm{N} \\
\end{array}$ & $\begin{array}{l}\text { Type of } \\
\text { Animal } \\
\end{array}$ & $2007 / 8$ & 2008/9 & 2009/10 & 2010/11 & $2011 / 12$ & $\begin{array}{c}2012 / \\
13\end{array}$ & 2013/14 & 2014/15 & 2015/16 & $2016 / 17$ & $2017 / 18$ & 2018/19 & TOTAL \\
\hline 1 & Cattles & 90.968 & 83.195 & 102.150 & 230.410 & 295.128 & 183.603 & 219.213 & 143.479 & 153.083 & 80.847 & 12.587 .040 & 8.417 .171 & $22,586,287$ \\
\hline 2 & Camel & 28,769 & 26,180 & 80,088 & 244,158 & 108,417 & 68,612 & 42,412 & 48,763 & 28,271 & 12,351 & $2,438,390$ & $6,367,828$ & $9,494,239$ \\
\hline 3 & Sheep & 140,290 & 98,482 & 137,576 & 146,787 & 355,838 & 387,989 & 321,962 & 299,677 & 398,648 & 165,320 & $6,549,416$ & $9,060,880$ & $18,062,866$ \\
\hline 4 & Goat & 31,197 & 5,182 & 11,618 & 15,101 & 24,505 & 34,104 & 37,084 & 27,691 & 82,377 & 20,962 & 187,152 & 247,673 & 724,646 \\
\hline 5 & Others & 900 & 1,640 & 2,318 & 364 & 1,121 & - & 30 & 10 & 26 & 82 & 9,085 & 31,200 & 56,776 \\
\hline & $\begin{array}{l}\text { Grand } \\
\text { Total }\end{array}$ & 292,124 & 214,679 & 333,752 & 636,822 & 785,078 & 674,309 & 620,727 & 519,620 & 662,405 & 279,562 & $21,781,083$ & $24,124,752$ & $50,924,914$ \\
\hline
\end{tabular}

Table 2. Revenue gained from live animal export in Million USD

\begin{tabular}{|c|c|c|c|c|c|c|c|c|c|c|c|c|c|c|}
\hline No & $\begin{array}{l}\text { Type of } \\
\text { Animal } \\
\end{array}$ & 2007/8 & 2008/9 & 2009/10 & $2010 / 11$ & 2011/12 & $2012 / 13$ & 2013/14 & $2014 / 15$ & $2015 / 16$ & $2016 / 17$ & $2017 / 18$ & 2018/19 & Total \\
\hline 1 & Cattles & 21.77 & 35.67 & 47.66 & 89.34 & 128.09 & 90.89 & 124.50 & 87.11 & 92.05 & 48.45 & 22.50 & 14.55 & 802.58 \\
\hline 2 & camel & 10.24 & 12.08 & 36.95 & 28.99 & 55.69 & 48.11 & 33.96 & 37.64 & 20.63 & 7.03 & 3.52 & 10.08 & 304.92 \\
\hline 3 & Sheep & 5.73 & 4.26 & 5.65 & 7.54 & 22.53 & 25.44 & 25.29 & 21.93 & 29.36 & 10.62 & 15.18 & 20.12 & 193.66 \\
\hline 4 & Goat & 1.20 & 0.22 & 0.44 & 0.69 & 1.29 & 1.90 & 3.09 & 1.80 & 5.74 & 1.35 & 0.44 & 0.54 & 18.71 \\
\hline 5 & Others & 0.00 & 0.01 & 0.01 & 0.00 & 0.02 & - & 0.01 & 0.00 & 0.00 & 0.00 & 0.17 & 0.13 & 0.34 \\
\hline & Grand Total & 38.95 & 52.24 & 90.71 & 126.56 & 207.64 & 166.34 & 186.86 & 148.49 & 147.78 & 67.45 & 41.80 & 45.42 & $1,320.23$ \\
\hline
\end{tabular}

Source: ERCA, export data

\section{Ethiopian Meat Export Trends (2008/9 to 2018/19 EFY)}

Before ten years, there were only four export abattoirs having production capacity of 30,380 (23,180 tonnes sheep and Goats meat, and 7,200 tonnes beef meat) generated 15.43 million USD per a year. Then after, government paid attention for the sector's investment to increase the number of export abattoirs as well as their production capacity; the number of export abattoirs increased from Four (2007/8 EFY) to Eleven (2018/19 E.C). The abattoir's production capacity per year also increased to (56,556 tonnes sheep and Goats, and 40,411 tonnes beef meat); the foreign currency earnings from meat export also dramatically increasing from 15.72 million USD (2007/8) to 92.65 million USD (2018/19). Starting from 2013/14 to 2017/18, Ethiopian meat export was increasing by an average of $5 \%$ per year, whereas live animal export was decreasing by $24 \%$ at the same time. See Figure 1 below. 


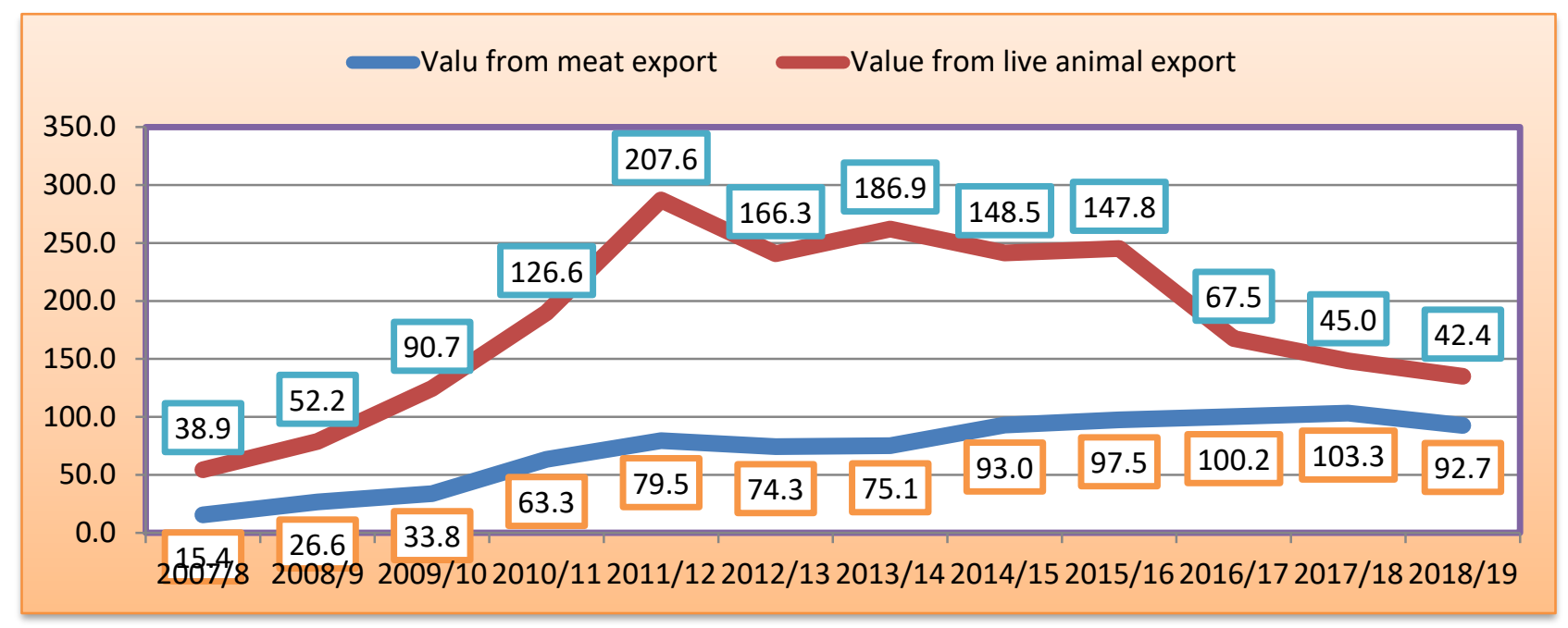

Figure 1. Meat and live animal export trends

Source: Ethiopian revenue and customs authority export data

As we understand from the above figure, the Ethiopian live animal export was increasing 2009/10 to 2013/14 EFY, and became decline after. The major reasons for live animal export declination were disease, illegal trade, market destination, lack of quarantine services, and payment with liability/credit, which may cause for risk on exporters (data collected).

\section{Market Destinations}

According to ERCA 2018/19 report market destination of Ethiopian live animal export before three years was mainly the neighboring countries; Somalia, Sudan, Yemen, Egypt, and other middle east countries. Now days, the market destination of meat and live animals was almost the same, this implies that the buyers also may be the same. United Arab Emirates and United kingdom of Saudi Arabia takes more than 85\% share of meat market destination.

\section{Status Meat and Live Animal Export}

According to ERCA report livestock products export have (195.17 million USD) 8.5\% share from the whole country's export in general, and Meat and Meat products takes $4 \%$, where as live animal takes only $2 \%$ share in particular, 2018/19 EFY. Ethiopia exports approximately 20,000 tonnes meat and meat products annually. It have about (92.65 million USD) $47.5 \%$ share from the whole livestock products (meat, leather, milk, bee products) export in the same year. From this about 80.35 million USD (86.7\%) gained from Sheep and Goat meat, 6.2 million USD (6.73\%) from beef and 6.06 million USD (6.55\%) was gained from Slaughter by-products export. ERCA, 2018/19.

According to the data available with Ethiopian Revenue and Customs Authority 2018/19, live animal exports contributed $2 \%$ of the earnings and meat exports shares only $4 \%$ from the country's export revenue earnings. Of the number of exported live animals, cattle accounted for $46 \%$, sheep 35\%, camels $13 \%$ and goats $6 \%$; whereas cattle contributed $67 \%$, camels $25 \%$ and shoats $8 \%$ to the revenue generated.

Table 3. Share of meat and meat products from Livestock products export in 2018/19 EFY

\begin{tabular}{|r|l|r|r|r|}
\hline SN & Product Name & $\begin{array}{l}\text { Volume in ton/000 } \\
\text { head }\end{array}$ & Value in Million USD & value share in \% \\
\hline 1 & Dairy products & $1,239.16$ & 0.12 & 0.005 \\
\hline 2 & Leather Products & $2,647.88$ & 56.57 & 2.46 \\
\hline 3 & Live Animals & $24,346.65$ & 45.83 & 1.99 \\
\hline 4 & Meat and Meat Products & $9,104.69$ & 92.65 & 4.04 \\
\hline 5 & Total & $47,338.38$ & 195.17 & 8.51 \\
\hline 6 & Others & & & 100 \\
\hline
\end{tabular}

Source: ERCA export data, 2018/19 EFY 


\section{Comparison Value Gained From Meat and Live Animal Exported, If Changed to Meat}

When we compare live animal export and meat export in last year's, the currency earned from live animal was decreasing, and foreign currency earned from meat was increasing. According to EMDIDI (2017), if we change live animal exported from 2008/9 to 2018/19 EFY to meat by the scale of (135 head = 1 ton for Goat and Sheep, and 10 head $=1$ ton for beef), we will get 269,613.61 tonnes of meat which can generate 1075.33 million USD without consideration of Offal, leather products value. The foreign currency revenue generated from meat export within the above years was 658.81 million USD, it is easy to compare the revenue generated from live animal export and the value will be got if changed to meat. The issue is not only currency, but also there are a lot of losses when we export live animal. Live animal export paves away for illegal cross border trade, because of geographical conditions Ethiopia, it is difficult to control. The other advantage of meat export is when industries are established, a huge number of citizens will get a job, is also used to transfer technology. See Figure 2 below.

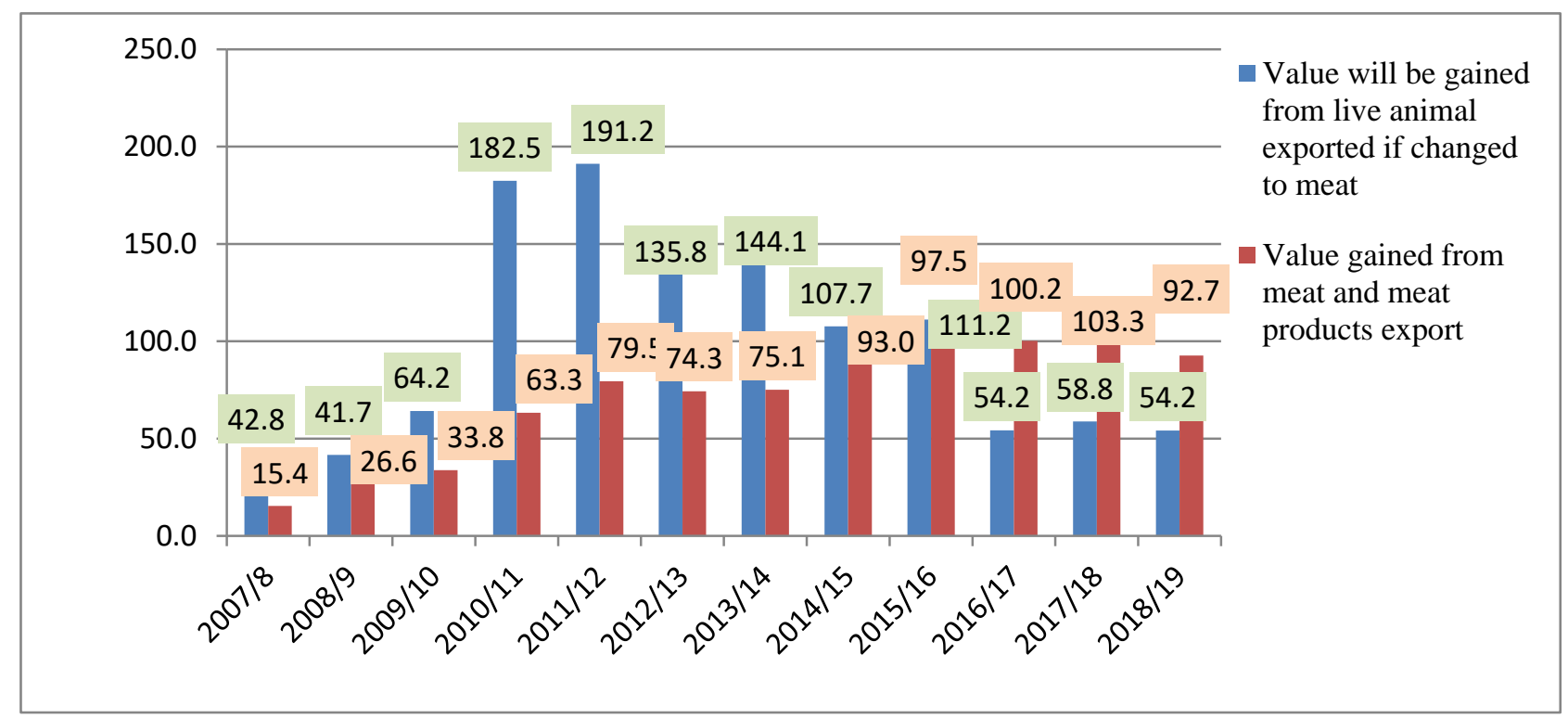

Figure 2. Comparison of meat and Live animal export, Value in million USD (2007/8 - 2018/19)

Source: ERCA, Annual reports

Footnote: The ratio of live animal to meat is (135 head :1 ton for sheep and Goat, and 10 head :1 ton for Beef and Camel)

\section{Opportunities and challenges of meat export in Ethiopia}

\section{Opportunities}

Ethiopia has some of the important opportunities influencing the meat and live animals industry, particularly the export sector (Ameha, 2011). The country has large livestock population with diverse and adaptable genotypes; diverse agro-ecologies for production of different types of livestock; government interest and support to the livestock industry; increasing number of export abattoirs like (Frigorico Boran Foods PLC/ Allana) which have the capacity of slaughtering 6,000 head of Sheep and goat, and 3,000 heads cattle per a day. Live animal exporters; the expansion of agro-industries and the increment of by-product feedstuffs allowing for enhanced productivity; proximity to Middle Eastern countries and adaptation of importing countries to the taste of Ethiopian animals; and high demand for meat and live animals including the domestic market. There is a large potential to expand Ethiopian meat exports to the Middle East if the value chain actors in Ethiopia meet export market standards (Ameha, 2011).

The most exportable live animals in Ethiopia were Borena breeds of cattle and small ruminants, Harar cattle, and for meat export goat, sheep and cattle from Borena, Guji, Sumale, Affar, Jinka and other arid and semi- arid areas of the country. The reason behind is demand similarity of importing countries and the localities in which animals grew. The share of live animal exports earnings has declined since 2012/13 (Figure 1). This was due to disease and increment of criteria from the buyers side. Increased domestic demand due to population growth and stagnant or declining production in the early 2013/2013 EFY led to major decrease in exports. 


\section{Value addition/ transport/ job creation - profitability}

Meat export is more valuable than live animal export, by many criteria. When we export meat, we will get more foreign currency from slaughter by products and Leather export. Now days, there great shortage of raw skin for Leather industries, so it will contribute as an input. On second GTP, the country have planned to export 1,885,958 animals in live, but if these animals slaughtered in the country, the above amount of raw skin and hide will be used as an input for leather industries. In second GTP, our country planned to earn 442.33 million USD from live animal export, but if the animals changed to meat in the country and exported, it is possible to get more than 700 million USD excluding slaughter by products and leather products value. This shows, it unnecessary to export animals in live (source, computed data).

Means of transport also more suitable for meat than live animal export. Live animal export have higher transport cost than meat export, and there are also a lot of risks when to export live animal; weight reduction, death, which will expose for high cost. In addition, the industry sector have the opportunity to create employment for citizens and transfer technology than live animal export. Ethiopian livestock are trucked from Ethiopian quarantine stations to the Djibouti quarantine facility, or trekked across the border into Somaliland and shipped from the ports of Barbara and Bossaso to Djibouti to the Middle East. This escorted the animals to be stressed and to reduce their body weight as well as reduction in quality of meat when the animals slaughtered. Livestock are also marketed through clan, sub-clan, and other kinship ties that are strongly maintained across international boundaries (Elisabeth, 2010).

\section{Transparency of Pricing System}

According to EMDIDI 2018/19 annual report, pricing system one of the problem of live animal export in Ethiopia. Most of live animal marketing from producer to end market was credit based, and caused for conflict between exporters and buyers. While, live animals supplied for export abattoir were purchased based on carcass based (after slaughtering), the price was mainly common at all export abattoirs, which will be changed by decision of both live animal traders and export abattoirs associations. So the pricing system of meat exporters and live animal traders is more transparent than purchase of animals for live animal export (computed data).

\section{Effective use of infrastructure}

It is obvious that, distribution of infrastructure in Ethiopia is related to the development of urbanization, and rural areas were abused. Today's meat and live animal export in Ethiopia, the main source of animal is arid and semi-arid areas of the country like; Borena, Somali, Guji, Jinka, Bale and Afar (Kefyalew, 2012). Those areas have no enough infrastructure road, electricity, market centers etc. In relation to effective use of infrastructure, meat export is more profitable than live animal export, due to different reasons. Firstly, meat export is undertaken only through legal way, and there will be no problem of logistics, road and other transportation facilities. Secondly, most of export abattoirs are located around Addis Ababa international airport, so that it is very easy to get all services required for export process (Kefyalew,2012).

\section{Foreign currency earning}

According to Ethiopian Revenues and customs authority, 20117/18 export data about 103 million USD was gained from meat export annually. In addition, there were another slaughter by-products; offal, skin and hides generating foreign currency revenue. The demand of slaughter by-product was increasing from year to year, its market also expanding even to Europe and United States of America markets. More than 6.23 and 60.21 million USD was gained from slaughter by-products and Leather products respectively in 2018/19 EFY. This indicates exporting live animal is not recommendable, than meat in Ethiopia (computed data).

\section{Challenges}

\section{Lack of end market destinations}

According to ERCA 2018/19 report, Ethiopia is exporting meat and meat products to different African and middle east countries. United Arab Emirates is the largest importer of meat buying 58\% of the total meat exported followed by the Kingdom of Saudi Arabia with 30\% and Bahrain (4\%) in 2018/19 EFY. Yemen and Somalia stood 1st and 2nd importers of live animals, Somalia was primarily for re-export to other countries. (ERCA, 2017/18).

\section{Shortage of slaughter animals supply}

It has been observed that the live animal throughput is inadequate. As a result, the existing meat processing facilities operate at less than $40 \%$ of their operational capacities( EMDIDI, 2018/19). This is apparently due to inadequate supply of the required quality live animals for meat processing by the export abattoirs (Kefyalew, 2011). The export abattoirs are competing for the domestic supply of live cattle and sheep and goats with the demand for live animals for domestic consumption, and for formal and informal (cross-border) trade (Asfaw and Mohammad, 2007). 
The legal export of both live animal and processed meat is thus constrained due to shortage legal systems created by the illicit export. According to Sintayehu et al. (2010), the reported factors contributing to large volumes of informal livestock trade and exports are onerous procedures required to export formally including export licenses, quarantine, banking clearance for remitting foreign exchange, minimum weight restrictions, and informal minimum price requirements (Kefyalew, 2011).

Better prices and more reliable market across the border; poor market linkages, financial and non-financial advantages to informality, including taxation, black market foreign exchange rates, lack of bureaucratic delay and clan and linguistic ties contributed to large volume informal livestock trade and exports (Ameha,2011).

\section{Illegal cross border trades}

According to Kefyalew, informal live animal trade from eastern Ethiopia (Somali Region) to Somaliland represents the largest share of cross-border trade in terms of volume and value. The majority of animals exported through this channel are Somali Blackhead or fat-tailed sheep, followed by goats, cattle and young camels (all male) (ERCA, 2017/18 E.C). Sheep and goats account for the vast majority of exports to Somaliland. Some livestock is also exported informally.

Recent studies estimate annual illegal flow of livestock through boundaries to be as high as 320,000 cattle (Workneh, 2006). This makes the actual performance to remain very low, leaving most (55 to 85\%) of the projected livestock off take for the unofficial cross-border export (Kefyalew, 2015). The immediate destinations of this illegal trade are Djibouti, Somalia, and Kenya which re-export livestock and their products to different countries where they compete with the legal exporters from Ethiopia (LMA, 2001).

\section{High demand of meat in local market}

Recent years, the demand of meat in Ethiopia has become increasing (ERCA, 2018/19). When compared to export market price of the red meat $(4 \$ / \mathrm{Kg})$, the local market $(10 \$ / \mathrm{Kg})$ is very high, so government have to work on the whole policy directions to reverse.(computed data, 2019). The reason behind is improvement of society's life standard and lack of available supply in the country. In general, the major challenge of meat export in Ethiopia today is incompatibility of local market price which makes production cost meat high (computed data).

\section{Conclusion}

In conclusion, this review aimed to assess the impact of live animal export on meat export performance of Ethiopian, for the purpose of policy change. Ethiopia has one of the largest livestock populations in Africa. Livestock in Ethiopia provides draught power, income for farming communities, means of savings and investment and is an important source of foreign exchange earnings to the nation. There are different problems that hinder the export performance of Ethiopian meat, from those shortage of live animal have the Lion share. All export abattoirs have almost common requirements of live animal purchase depending on their customer interest.

Ethiopia has some of the important opportunities influencing the meat and other livestock products' industry, particularly the export sector . The country has large livestock population with diverse and adaptable genotypes; diverse agro-ecologies for production of different types of livestock; government interest and support to the livestock industry; increasing number of export abattoirs, Live animal exporters; the expansion of agro-industries and the increment of by-product feedstuffs allowing for enhanced productivity; proximity to Middle Eastern countries and adaptation of importing countries to the taste of Ethiopian animals; and high demand for meat and live animals including the domestic market. There is a large potential to expand Ethiopian meat exports to the Middle East if the value chain actors in Ethiopia meet export market standards.

However, current knowledge on meat and livestock market facing challenge; lack of slaughter animals supply, market destination, illegal trade, disease, inadequate to design any policy or institutional innovation to improve marketing for the benefit of the poor.

\section{Recommendations}

Based on problems identified on meat and live animal export status, opportunities and challenges, the researcher recommends as follows;

- Live animal export has to be banned to improve the foreign currency revenue gain from livestock resource.

- Government should be work to expand market destinations for meat products, so that it may used as a major source of foreign currency.

- Live animal export has to be stopped to solve illegal cross border live animal trade.

- The study has to be undertaken to indentify the profitability of live animal and meat export in Ethiopia.

- The government have to work on mass production by establishing ranches, to create sustainable supply. 


\section{Lists of Acronyms}

EFY - Ethiopian Fiscal Year

EMDIDI - Ethiopian Meat and Dairy Industry Development

ERCA - Ethiopian Revenues and Customs Authority

FAO- Food Aid Organization

GDP- Gross domestic product

GTP I - The first Ethiopian Growth and Transformation Plan

GTP II - The second Ethiopian Growth and Transformation Plan

MoTI - Ministry of Trade and Industry

UN - United Nations

USAID - United States Agency for International Development

USD- United States Dollar

\section{References}

Ameha, S. (2011). Export requirements for meat and live small ruminants: How can development agents assist producers to improve small ruminant export? Techn. Bull, (47).

Asfaw, N., \& Jabbar, M. (2007). Commercial Off-take of Cattle under Smallholder Mixed Crop-Livestock Production System in Ethiopia. Its Determinants and Implications for Improving Live Animal Supply for.

Elias, M., Berhanu, G., Hoekstra, D., \& Jabbar, M. (2007). Analysis of the Ethio -Sudan cross-border cattle trade: The case of Amhara Regional State. IPMS (Improving Productivity and Market Success) of Ethiopian Farmers Project Working Paper 4. ILRI (International Livestock Research Institute), Nairobi, Kenya. 41 pp.

Elisabeth, F. (2010). End Market Analysis of Ethiopian Livestock and Meat. A desk study Micro report of USAID, Number 164, Ethiopia.

Ethiopian meat and dairy industry development institute annual reports, 2018/19.

Kafyalew, \& Addis. (2015). Beef Cattle Production System and Opportunities for Market Orientation in Borena Zone, Southern Ethiopia. A Thesis Submitted to the Department of Animal Science, School of Graduate Studies. Haramaya University, Ethiopia.

Livestock Marketing Authority (LMA) (2004). Meat Exports Market Study, MoARD, Addis Ababa Ethiopia. In: New Partnership for Africa's Development (NEPAD) - Comprehensive Africa Agriculture Development Programme (CAADP), 2005 Ethiopia: Investment

Mohammad, J. N. (2007). Commercial 0ff take of Cattle under Smallholder Mixed Crop-Livestock Production System in Ethiopia, its Determinants and Implications for Improving Live Animal Supply for Export Abattoirs. ILRI, Addis Ababa, Ethiopia.

Nell, A. J. (2006). Quick scan of the livestock and meat sector in Ethiopia: Issues and opportunities. Wageningen University and Research Centre, Wageningen International.

\section{Copyrights}

Copyright for this article is retained by the author(s), with first publication rights granted to the journal.

This is an open-access article distributed under the terms and conditions of the Creative Commons Attribution license which permits unrestricted use, distribution, and reproduction in any medium, provided the original work is properly cited. 